\title{
Narratives of Desire, Love, Imagination, and Fluidity: Becoming an English Teacher in a University Preparation Program
}

Narrativas de deseo, amor, imaginación y fluidez: devenir profesor de

inglés en la universidad

Narrativas de desejo, amor, imaginação e fluência: tornando-se professor de inglês na universidade

Maria Cristina SARASA

http://orcid.org/0000-0003-0849-29I I.

Universidad Nacional de Mar del Plata, Argentina.

mcsarasa@hotmail.com

Luis Gabriel PORTA

http://orcid.org/0000-0002-5828-8743.

Universidad Nacional de Mar del Plata, Argentina.

luisporta5ı@@gmail.com

Received: 2018-04-16

Accepted by peers: 2018-05-24
Sent for peer review: 2018-04-24

Approved: 2018-06-13

To reference this article in APA style / Para citar este artículo en APA / Para citar este artigo Sarasa, M. C. \& Porta, L. G. (2018). Narratives of desire, love, imagination, and fluidity: Becoming an English teacher in a University Preparation Program. LACLIL, 11(1), 141-163. DOI: 10.5294/laclil.2018.11.1.7 
ABSTRACT. This is a narrative study into the co-construction of teaching identities narrated by twenty-four undergraduate students in the context of an English language teacher education program in Argentina. Teacher identities are defined in the literature as co-authored stories of living and becoming. Our method uses narrative inquiry to study lived experiences as co-narrated phenomena. The narrative analysis of different texts gathered in the teacher education program allowed the co-composition of each participant's identity story. Results first display thematizations of identity strands in these narratives involving emotions-love, desire, imagination, and fluidity. Next, participants' negotiation of their processes of becoming through these emotions are retold. The discussion examines results considering state-of-the-art literature. The conclusions summarize the implications of the research for English language teacher initial university education.

Keywords: Second language instruction; teacher education; identity; qualitative analysis.

RESUMEN. Este estudio narrativo aborda la co-construcción de la identidad docente de veinticuatro estudiantes de pregrado en el contexto de un profesorado de inglés argentino. En la literatura, la identidad denota relatos co-compuestos sobre vivir y devenir. La indagación narrativa es el método que examina la experiencia como fenómeno co-relatado. El análisis narrativo de textos recogidos en el programa de formación permitió co-escribir veinticuatro narrativas individuales. Los resultados despliegan primero tematizaciones de emociones sobre devenires identitarios: amor, deseo, imaginación y fluidez. Luego, retoman las voces de los participantes, contando sus negociaciones del sobrevenir mediante el amor, el deseo, la imaginación y la fluidez. La discusión examina los resultados siguiendo al estado del arte disciplinar. Las conclusiones sugieren implicancias para la formación inicial del profesorado universitario de inglés.

Palabras claves: enseñanza de segundas lenguas; formación docente; identidad; análisis cualitativo.

RESUMO. Este estudo narrativo aborda a co-construção da identidade docente de vinte e quatro estudantes de graduação no contexto de um professor de inglês na Argentina. Na literatura, a identidade denota histórias co-compostas sobre viver e devir. A investigação narrativa é o método que examina a experiência como um fenômeno co-relatado. A análise narrativa dos textos coletados no programa de treinamento permitiu co-escrever vinte e quatro narrativas individuais. Os resultados mostram, primeiro, tematizações de emoções sobre devires de identidade: amor, desejo, imaginação e fluência. Em seguida, retomam as vozes dos participantes, contando suas negociações do futuro através do amor, desejo, imaginação e fluência. A discussão examina os resultados após o estado da arte disciplinar. As conclusões sugerem implicações para a formação inicial de professores universitários de inglês.

Palavras-chave: ensino de segundas línguas; formação de professores; identidade; análise qualitativa. 


\section{Introduction}

This paper presents a narrative inquiry into the co-construction of future English language (EL) teacher identities narrated by twenty-four undergraduate students attending an Argentinian EL teacher education program. Its research question concerns how participants' narratives (re)negotiate their meanings of becoming EL teachers.

We undertook this study in our under-researched national context because EL teacher identity construction has acquired global relevance in formation programs, signaling professional interest in the process of learning to be teachers (Pinnegar \& Hamilton, 2015). We are committed to a narrative definition of identity as co-authored stories to live by (Clandinin \& Huber, 2005). Thus, we believe that, at the core of teacher narrative identity, emotions play key roles in cognition and action (Golombek \& Doran, 2014).

Our research methodology is narrative inquiry, which embraces lived experiences as co-narrated phenomena and is dedicated to an ethics of care (Clandinin, 2013). Accordingly, the narrative analysis of the twenty-four undergraduates' stories gathered in the ETEP (English teacher education program) allowed the co-composition of individual narratives with participants. We saw four different meanings of being EL teachers during initial education that emerged from our thematization of throughlines in these co-authored stories. They involved desire, love, imagination, and fluidity. Then, we needed to interweave participants' voices to retell how they (re)negotiated their processes of becoming, knowing, and doing through their love, desire, imagination, and fluidity.

Our inquiry allowed us to resignify our thematizations and renegotiations by considering the literature and to co-create experiential transformative knowledge in the ETEP as participants generated personal and professional insights through their narratives. Accordingly, we explored some core issues in EL teacher education that should be addressed in our milieu as they bear key implications for the profession. 


\section{EL Teacher Education in Argentina}

Argentinian EL teacher education originated in 1904 when the first EL tertiary level state teacher education program was founded in Buenos Aires city. Originally aimed at enhancing secondary schoolteachers' language development following near native-speaker standards, Argentinian EL teacher education has faced tensions concerning its knowledge base, which has tended to emphasize linguistic skills at the expense of disciplinary content and pedagogy. It is divided into two higher education spheres: one comprising mostly state and sometimes private universities, and the other including state or private non-university teacher education institutes (Banfi, 2013).

Most Argentinian EL teacher education programs do not administer selective entry tests, since these are banned by federal and provincial legislation. However, their instructors demand high initial levels of linguistic proficiency corresponding to Level C1 in the Common European Framework of Reference for Languages. Thus, most first-year students are supposed to have acquired English through prolonged tuition at private schools or academies (British Council, 2015). On the one hand, this unofficial prerequisite results in dropout and attrition rates and graduation slowdown for those lacking expected entry levels. On the other hand, this means that graduate English teachers are highly qualified. Currently, there are not enough certified EL instructors when English became compulsory in primary curricula in the 1990s-after having been introduced in secondary education during the second half of the nineteenth century (Porto, 2016). At university level, several postgraduate programs have been created in the last decades, although graduates may still study abroad or opt for national interdisciplinary programs, especially if aiming at doctorates.

In 2011, the National Institute for Teacher Education and the University Policies Secretariat (Instituto Nacional de Formación Docente \& Secretaría de Políticas Universitarias, 2011) drafted a project for improving secondary schoolteachers' foreign languages education. The document suggests teacher education should concentrate on four foci: learning, citizenship, interculturality, and discursive practices while emphasizing reflection, biographies and identities, alterity, sociocultur- 
al mediation, research and academic writing practices, and digital literacy. Most teacher education programs nationwide need to articulate their curricula to cover these foci (Banegas, 2014).

\section{Literature Review}

Language is a complex repertoire of resources deployed for communication and identity construction, which is located in language as social, relational, and processual. Likewise, it is expressed in language because, when people represent themselves and others, they are performing ways of belonging and interpreting their expressions since "at least some language users, at least some of the time, hold passionate beliefs about the importance and significance of a particular language to their sense of 'identity'” (Creese \& Blackledge, 2015, p. 25). Multilingual speakers decide who they want to be by choosing relevant language practices, including self-representations, plus the shaping power of the educational contexts where those representations are enacted.

Over ten years ago, Varghese, Morgan, Johnston, and Johnson (2005) advocated paradigmatic dialogues and the use of multiple approaches to identity, among which they included narrative ways of knowing. They identified two ways of theorizing on EL teacher identification. One concerned classroom practices and beliefs (Johnson, 1992). The other addressed social, cultural and political dimensions of teaching (Norton, 1997). ELT has regarded identity as multiple, fluctuating, struggling, and discursively co-constructed and negotiated in social, cultural, and political contexts. Concurrently, Sfard and Prusak (2005) likened its building to story-telling. Defining identities as stories, they found an operational conceptualization, since narratives reify when identity takes the form of a temporally emplotted story (McAdams, 2018).

Identity as stories suggests that it is linked to knowledge and context and thus can be "understood narratively." Teachers are "living stories on storied landscapes." Their identities are "interwoven with the lives they live and the contexts in which they compose them." A "teacher's identity is... the unique embodiment of his/her stories to live by, stories shaped by the landscapes past and present in which s/he lives and works" (Clandinin \& Huber, 2005, p. 44). 
Narrative research considers stories as reflections, makers, composers, and "sources for theorizing and exploring" it (Spector-Mersel, 2011, p. 173). This focus indicates a "shift" in teacher education "from the concept of 'learning' to the concept of identity development" (Meijer, 2017, p. 210).

These construction processes are sustained by the notion of becoming within educational contexts through linguistic negotiationsstruggling to represent what the experiences of coming to be a teacher mean. Therefore, identity relates to living, telling, retelling, and reliving these negotiations (Huber, Caine, Huber, \& Steeves, 2013). In this sense, becoming is more constructive than simply being (Orland-Barak, 2016). It is a unique, emerging, dynamic, and creative process.

Teacher identity building is pertinent to research, teaching, policies, and teacher education and development (Varghese, Motha, Trent, Park, \& Reeves, 2016). Ecological perspectives stress its negotiated, co-composed, and co-constructed nature (Edwards \& Burns, 2016). Furthermore, The Modern Language Journal's supplement on "Transdisciplinarity and language teacher identity" (Costa \& Norton, 2017) connected EL teacher education to good language teaching by drawing on the Douglas Fir Group paper (2016), stating that language learning encompasses socio-political, institutional, and personal self-construction, which can be studied by thematic transdisciplinary dialogues.

Relevant articles from South America remain scarce in the literature (Norton, 2016a). Surveying developments in pedagogical and research areas during TESOL Quarterly's history, Canagarajah (2016) observed the rarity of contributions from this area. In their summary on Argentinian ELT during 2007-2013, Porto, Montemayor-Borsinger, and López-Barrios (2016) introduced the first review ever published from a Latin American country. They examined eighty-eight articles in peer-reviewed conference proceedings, academic journals in English and Spanish, and one edited collection. They considered this research was "high-quality situated" (p. 356), covering affect, interculturality, teacher education and development, CLIL, CALL, ESP and EAP, and evaluation, materials design, and educational experiences.

One exception is Initial English language teacher education: International perspectives on research, curriculum and practice (Banegas, 2017), problematizing teacher education through national case studies. It includes 
two Argentinian tertiary level examples. The other is English language teaching in South America: Policy, preparation and practices (Kamhi-Stein, Díaz Maggioli, \& de Oliveira, 2017), gathering works by teachers and educators in Argentina, Brazil, Chile, Colombia, Ecuador, Peru, Uruguay, and Venezuela. A relevant contribution (Salinas \& Ayala, 2018) addresses the case of two Chilean EFL student-teachers' identity development. Results indicate that interactions in the learning environment and during the practicum changed self-images and were dealt with by problem solving, adaptation, and negotiation.

Becoming and knowing relate to feeling (Mercer, Oberdorfer, \& Saleem, 2016). Teachers engage cognitively, affectively, and relationally telling negotiated visions of their knowledge and emotions concerning their professional development. Emotion involves "socially constructed, personally enacted ways of being that emerge from conscious and/or unconscious judgments regarding perceived successes attaining goals or maintaining standards or beliefs during transactions as part of social-historical contexts" (Schutz, Hong, Cross, \& Osbon, 2006, p. 344, authors' italics). Emotions are key components of professional identity as they lie at the core of the sense attributed to turning into a teacher (Chen, 2016; Shapiro, 2010). They draw on interdisciplinarity concerning the mind and the body, the personal, and the social. Thus, feelings and becomings are included in teacher identification development, underscoring interaction between emotions, cognition, and activity (Golombek \& Doran, 2014).

\section{Method}

The research methodology is narrative inquiry, embracing "narrative as both the method and the phenomena of study." It delves into "experience as expressed in lived and told stories." Thus, "narrative inquiry involves the reconstruction of a person's experience" (Pinnegar \& Daynes, 2007, p. 5) exploring it as stories lived, told, retold, and relived (Clandinin, 2013).

This paper summarizes a narrative inquiry carried out by the authors. The participants were twenty-four undergraduates attending a sophomore EL skills subject in an Argentinian ETEP, taught at the 
school of humanities within an Argentinian state university located in the country's most densely populated province. This program has operated for over four decades. Its present faculty includes some forty members, who are mostly locally born and speak English as an International Language (EIL) with a high degree of proficiency. Some instructors have obtained masters or PhDs in Literature, Linguistics, Language Teaching, and Education, both locally and abroad. The students currently total some 250 undergraduates. They face the same entry and trajectory challenges as those described for the country in general.

This ETEP teaches a four-year course of study organized into four curricular areas. The first comprises subjects teaching the four macro skills, aiming at very advanced linguistic proficiency. The second includes courses focusing on the grammatical and phonological foundations of Standard English. The third involves courses surveying UK and USA histories and literatures to encourage intercultural awareness. Finally, subjects in the pedagogic area focus on education, curriculum development, Second Language Acquisition (SLA) theory and research, microteaching, and practicum experiences. Most courses are imparted in English, using texts aimed at analogous courses for NSEs in higher education. This ETEP must still harmonize its curriculum with the National Institute for Teacher Education and the University Policies Secretariat's project for enhancing foreign language teachers' education (Instituto Nacional de Formación Docente \& Secretaría de Políticas Universitarias, 2011).

The participants' biographical data is summarized below in Table 1.

During one semester, the authors gathered the participants' home-written and in-class retold narratives. They were observers inside those classes where stories were told orally. These sessions were led by the assistant professor of the subject. Since the authors are professors in the ETEP, they followed ethical procedures by requesting, obtaining, and renewing the students' informed consent. Likewise, they observed relational ethics (Clandinin \& Murphy, 2009), involving consideration for students' privacy and stories, shielding them from undue researcher-participant asymmetries, and rendering inquiry actions transparent.

Instruments for gathering the oral and written narratives were adapted from those utilized by life story interviews (McAdams, 2018) 
Table 1. Participants' biographical data

\begin{tabular}{|c|c|c|c|c|c|c|c|}
\hline \multirow{2}{*}{$\begin{array}{l}\text { Assumed } \\
\text { Name }\end{array}$} & \multirow{2}{*}{ Reason } & \multirow{2}{*}{$\begin{array}{l}\text { Year of } \\
\text { Birth }\end{array}$} & \multicolumn{2}{|c|}{ Prior EL studies } & \multirow{2}{*}{$\begin{array}{l}\text { Length } \\
\text { (years) }\end{array}$} & \multirow{2}{*}{$\begin{array}{l}\text { Year } \\
\text { Entry } \\
\text { ETEP }\end{array}$} & \multirow{2}{*}{$\begin{array}{l}\text { Number of } \\
\text { Courses } \\
\text { Completed }\end{array}$} \\
\hline & & & School & Academy & & & \\
\hline Ant & Travelling Ant & 1990 & $\checkmark$ & $\checkmark$ & 8 & 2010 & 14 \\
\hline Cas & $\begin{array}{l}\text { Character from } \\
\text { Superna tural }\end{array}$ & 1993 & $\checkmark$ & & 13 & 2012 & 13 \\
\hline Clara & $\begin{array}{l}\text { Clarissa } \\
\text { Dalloway }\end{array}$ & 1991 & $\checkmark$ & $\checkmark$ & 6 & 2009 & 16 \\
\hline Coty & Pet name & 1993 & $\checkmark$ & $\checkmark$ & 9 & 2012 & 13 \\
\hline Emma & Emma & 1990 & $\checkmark$ & $\checkmark$ & 7 & 2009 & 13 \\
\hline Fátima & $\begin{array}{l}\text { The Hand of } \\
\text { Fatima }\end{array}$ & 1980 & $\checkmark$ & $\checkmark$ & 5 & 2011 & 11 \\
\hline Grian & Irish name & 1993 & $\checkmark$ & & 12 & 2012 & 15 \\
\hline Haven & $\begin{array}{l}\text { Adapted } \\
\text { Twilight } \\
\text { character }\end{array}$ & 1994 & $\checkmark$ & $\checkmark$ & 7 & 2012 & 11 \\
\hline $\begin{array}{l}\text { James } \\
\text { Nicholas } \\
\text { White }\end{array}$ & $\begin{array}{l}\text { English name + } \\
\text { White Fang }\end{array}$ & 1990 & $\checkmark$ & & 9 & 2010 & 11 \\
\hline Jo & Pet name & 1993 & $\checkmark$ & $\checkmark$ & 4 & 2012 & 12 \\
\hline Juana & Aunt & 1990 & $\checkmark$ & $\checkmark$ & 10 & 2012 & 13 \\
\hline Lily & $\begin{array}{l}\text { Harry Potter's } \\
\text { mother }\end{array}$ & 1994 & $\checkmark$ & & 13 & 2012 & 11 \\
\hline Maggie & Her dog & 1992 & $\checkmark$ & $\checkmark$ & 4 & 2010 & 12 \\
\hline Marilyn & Marilyn Monroe & 1992 & $\checkmark$ & $\checkmark$ & 6 & 2010 & 14 \\
\hline Polka Dots & Portfolio's cover & 1986 & $\checkmark$ & $\checkmark$ & 10 & 2006 & 20 \\
\hline Rose & Flower & 1993 & $\checkmark$ & & 7 & 2012 & 14 \\
\hline Rusa & $\begin{array}{l}\text { Blonde, blue- } \\
\text { eyed }\end{array}$ & 1991 & $\checkmark$ & $\checkmark$ & 9 & 2010 & 14 \\
\hline Savannah & $\begin{array}{l}\text { Character from } \\
\text { Dear John }\end{array}$ & 1995 & $\checkmark$ & & 9 & 2013 & 14 \\
\hline $\begin{array}{l}\text { Sheila } \\
\text { Tarnosky }\end{array}$ & $\begin{array}{l}\text { Father's } \\
\text { endearment }\end{array}$ & 1990 & $\checkmark$ & $\checkmark$ & 12 & 2010 & 20 \\
\hline Sofía & Sister & 1994 & $\checkmark$ & $\checkmark$ & 7 & 2013 & 10 \\
\hline $\begin{array}{l}\text { The } \\
\text { Married } \\
\text { One }\end{array}$ & Married student & 1987 & $\checkmark$ & $\checkmark$ & 8 & 2006 & 11 \\
\hline Tute & Pet name & 1985 & $\checkmark$ & $\checkmark$ & 10 & 2004 & 22 \\
\hline Unnamed & $\begin{array}{l}\text { Man with no } \\
\text { name }\end{array}$ & 1991 & $\checkmark$ & $\checkmark$ & 9 & 2009 & 11 \\
\hline Victoria & Middle name & 1985 & $\checkmark$ & $\checkmark$ & 9 & 2003 & 27 \\
\hline
\end{tabular}


and narrative inquiry into teacher education (Clandinin, 2013). Narratives' topics centered on participants' experiences concerning: the stories read, watched, and listened to; school and linguistic autobiographies; greatest teachers and real life-heroes; lives' turning points, greatest challenges, and wisest academic decisions; and self-identification.

When the semester ended, the authors kept in touch with participants individually or in groups, via face-to-face or virtual interactions. Through these encounters we, authors and participants, co-composed individual narratives and engaged in member-reflection (Tracy, 2010).

Each of the twenty-four narratives co-composed by the authors and the participants was emplotted by interweaving the following:

1. A quote excerpted from one of the participant's narratives, serving as throughline of the co-authored story.

2. Chosen pseudonym and reason for this option.

3. Date and place of birth.

4. Primary and secondary school autobiography, intertwined with linguistic autobiography, self-identification essay, best teacher narratives, and greatest challenge overcome.

5. University autobiography considering reasons for joining ETEP, year of entry, number of courses taken, GPA, general trajectory, life's turning point, and wisest academic decision.

6. Significant family story.

7. Tentative, future-oriented, closure.

The twenty-four co-composed narratives embody ways of understanding and thematizing processes of turning into EL teachers (Kim, 2015). The verb "to narrate" is rooted in the Latin gnoscere, i.e., to know (Van Manen, 1990). Narrative analysis agrees with the principles of narrative inquiry during which researchers and participants engage in the co-construction and renegotiation of stories' meaning (Cortazzi, 2001). The oral and written narratives gathered from each participant, the individual narratives co-composed by participants and authors, the interweaving of these co-created stories, and the resulting thematizations are part of a process of crystallization (Ellingson, 2009) through which multiple voices, storied experiences, and themes are illuminated and refracted, taking on new forms and deepening understanding. 


\section{Results}

Since it is impossible to present the twenty-four co-authored narratives, we present "snippets" of participants' words providing throughlines into their identity constructions (Craig, 2017). These offer a "preview" of these processes and allow for the interweaving and thematization of emerging teacher identities.

\section{Narrative thematizations of desire, love, imagination, and transit}

We thematize participants' identities by quoting throughlines retrieved from their individual narratives co-composed with the authors, as we co-emplotted the texts listed in the design. These guiding threads suggest that constructing future teacher identities engages the whole person in the negotiation of committing to this never-ending process of coming to be a teacher (Gale \& Parker, 2014). These routes can involve desire, love, imagination, and fluid transits.

First, as regards desire, there are participants who long (Zembylas, 2007) to graduate as English teachers within a near future, expressing their desire as follows:

Clara: "I am person who wants to graduate from university to see my dreams and those of my parents' fulfilled."

Coty: "I really feel that teaching, especially children, is my vocation and I want this for the rest of my life."

Haven: "I like languages and I want to dedicate my life, for the most part, to them but I also like teaching."

Jo: "Being an English teacher is what I want to do for the rest of my life." Marilyn: "I realized that I wanted to become a teacher... I dreamt of working at school, sharing my knowledge and being a caring teacher."

Rusa: "After going through my first teaching experiences, I realized that I really enjoy teaching. I confirmed that this is what I want to do for the rest of my life, and that I am on the right track."

Savannah: "English is what I want for the rest of my life."

Sheila Tarnosky: "What I truly want is to be an English teacher." 
Tute: "I want to feel the wonderful pride that one is sure to enjoy when introducing oneself as a professional English teacher."

The second thematization involves love, when participants verbalize their passion (Ramezanzadeh, Adel, \& Zareian, 2016) for the English language and for teaching, with the following expressions:

Cas: "I love languages and I like the idea of sharing knowledge with others."

Grian: "I love English and I really enjoy learning more about the language and the culture. At first I wasn't really interested in teaching but after a while I found out I loved it."

Polka Dots: "I love English, I love the way it sounds, I love learning about the language and being able to answer my students' questions. I found something I thought I could be good at and I held on to it."

Rose: "I love teaching and I love English. My goal has always been to teach children."

Sofía: "I love the language and I love the idea of transmitting what I know to other people. I am fascinated with the idea of being part of children's lives."

The Married One: "Today, we are both studying and working as English teachers, we love what we do and we are amazed at the things life has to offer."

Victoria: "I am very passionate about languages. My desire is to teach and have the same impact on my students' lives as my high school teachers had on mine."

The third theme embodies imagination. Some participants envision their teacher identities as a process they will accomplish in the future (Norton, 2016b). In their own words:

Emma: "I had to work extremely hard and retake several subjects. Even though I am still going through this complex process, I think this is the way to achieve my goal: becoming an English teacher."

Fátima: "I have convinced myself that I am going to try hard, even though it takes me three times more than the time it is supposed to take."

James Nicholas White: "Not everyone can get to be a funny or likeable teacher, but with enough hard work and planning I am certain that anyone can find his/her own style and become a great teacher." 
Juana: "I can see myself as an English teacher in the future."

Finally, the remaining participants navigate a fluid transit towards graduating as English teachers: the starting point is blurred while the finish line remains undetermined (Giroir, 2014):

Ant: "I strongly believe that challenges are opportunities based on decisions and that, once we take them, we embark on a journey with plenty of emotions and uncertainties that will mark our future lives."

Lily: "I am happy with who I am now. I will continue to move forward and, step by step, I will become the person I dream of being, no matter how long it takes."

Maggie: "I am studying something that does not fulfil me a hundred per cent but it paves the way to accomplish my final goal. I am sure I will overcome it, as I want to keep on studying to become an interpreter."

Unnamed: "I do not know what the future holds for me, but I am certainly happy with the prospect my decision of entering the ETEP gave me."

Concisely, these narratives of desire, love, imagination, and fluidity suggest that, on the one hand, some participants are sustained by their emotions to commit to the program and to follow a relatively direct route. On the other hand, there are those who grapple with their studies and with themselves before fully committing to their paths.

\section{Becoming a teacher: being, knowing, and doing}

Several participants stated that they see themselves as teachers. Some manifested their desire (Clara, Coty, Jo, and Marilyn) to graduate as teachers and some their love for the profession and the language (Married and Rose). Clara indicated that "to become a teacher we must not only graduate but also like what we do and feel that what we teach really touches our students." Coty explained that she works with "little kids" and this "is a dream come true... The call me 'teacher'... I feel I am a teacher." Jo works with adults and considered that "it's cool when forty-year old guys call you 'teacher.' They are interested and you can explore... cultural stuff. I enjoy what I do." Marilyn claimed that "I con- 
sider myself a teacher. I like it when I feel students really learn, understand, and get good grades." For his part, Married believed that "your students award your English teacher diploma." Next, Rose stated that:

I consider myself a teacher... I have only coached and taught some microteaching experiences... but I transmitted knowledge to my students, not simply content but also strategies and values... I dealt with the usual challenges: having students who are not interested or who hold incredible potential but cannot achieve it.

The following set of participants (Cas, Grian, Fátima, and Tute) inhabit liminal, in-between, spaces. Cas loves teaching although she confessed that "I cannot identify myself as a teacher... I still see myself more as a student. I feel it's a question of time, of getting used to a different role." Grian also loves English and teaching. She considered that there exist teachers who simply work with or without a degree and professionals who engage in development. Fátima imagines graduating as a teacher and explained that:

\begin{abstract}
I have started working... But I don't know if I can consider myself a teacher. On the one hand, I do because I teach and transmit knowledge to my students helping them learn and doing my best. On the other hand, to be a "teacher" we must fulfill certain requisites (having a degree). It is also true that there are many teachers who hold a degree and don't deserve to be called teachers.
\end{abstract}

Tute longs to graduate and insightfully confessed: "I have long found myself in-between two worlds. As a teacher, I used to leave college and change roles in half an hour." He considered that a teacher simply teaches, while a professional exhibits a code of behavior.

The next participants are working as teachers. Some want to graduate (Rusa, Savannah, and Sheila); others imagine they will do so (Emma and Juana); and the rest love teaching (Polka Dots and Victoria). Lacking her teaching degree weighs on Rusa, who confessed that "I don't feel one hundred percent a teacher." Savannah explained that:

I consider I am partly a teacher. I've never had my own course for a whole year. I feel I'm different from the rest. I haven't finished my course of study although I've met many teachers who hadn't graduated but their stance and their attitudes belonged to ['real'] teachers. I lack experience and self-confidence so I cannot call myself a teacher. 
Sheila never introduces herself as a teacher and admitted that "I have a thing about not having the degree." Polka indicated that being a teacher "involves enjoying the freedom to deviate from the curriculum to teach other stuff rather than rushing to fulfill the objectives imposed by the academic coordinators." Victoria works full-time at a private school and conceded that: "I have gained experience but I feel I am not a teacher one hundred per cent because I don't have a degree." Emma is a coach at her alma mater and felt shocked when addressed as "teacher" since she has "not graduated." Finally, Juana indicated that "if I were a graduate it would annoy me to see people who don't have a degree calling themselves teachers [but] if I am hired and called 'teacher' I'm not going to claim I'm not one."

Within the last group we find participants who do not consider themselves teachers: Ant, Lily, Maggie, and Unnamed, whose identities are in transit; Sofía, who loves English and teaching; Heaven, who wants to be a teacher; and James, who imagines being a teacher. Ant said that "I've taught some private classes but I'm not self-confident enough to be able to transmit knowledge." Lily felt that "I don't consider myself a teacher. It's not fair for those who have graduated. I still have a lot to learn." Maggie explained that:

I started working last year because I think it's the best way of gaining experience and becoming a teacher. But it's unfair to compare myself to other people who not only tried very hard to get a degree but who also have a long trajectory.

Unnamed works at a theater complex. He is an avid and knowledgeable reader, movie watcher, and opera fan and singer. Sofía maintained that:

There is a lot of stuff I will learn as I start teaching but I believe I still have to learn things that the course is going to teach me. I have a lot of respect for those teachers who have devoted themselves to their development so I don't feel comfortable calling myself a teacher.

Haven stated that "I am still not fully prepared to go out and teach." Finally, James expressed that "my jobs as a teacher have been few and far between so I cannot consider myself a teacher yet." 
Briefly, these interwoven narratives about future teachers' identities show complex plots. Although nobody has graduated yet, some already consider themselves teachers; others express an oxymoronic student-teacher nature; several participants differentiate between graduating as teachers from working as such; and the rest do not regard themselves as teachers since they lack the qualifications the degree bestows.

\section{Discussion}

We now reexamine our research question concerning how participants' narratives (re)negotiate the meanings of their becoming EL teachers. The narrative threads we have interwoven address the particularities and generalities of narrative identities that tell about being oneself as another (Ricoeur, 1990).

These future teachers' identities will continue developing. Fluid identifications suggest these shifts: "I am happy with who I am now. I will continue to move forward, and step by step, I will become the person I dream of being, no matter how long it takes" (Lily). These problematics of (be)coming and be(com)ing — coming (in)to be(ing) (Flores, 2017) - are captured by part of the title from a paper on student-teachers' narrative representations of attachment, "Narratives of 'doing, knowing, being, and becoming'" (Kearns \& Hart, 2017). This sense of beginning to be, as part of emerging adults' identity construction processes (Arnett, 2014), was manifested during a personal exchange with Haven, who affirmed: "I'm 'adulting'."

These processes involve doing and knowing. Our throughlines indicate that those who desire to be teachers also wish to graduate, make dreams come true, work, share, feel, introduce themselves, devote themselves to a task, and teach. In Jo's words: "Being an English teacher is what I want to do for the rest of my life." These wishes emerging from our narratives relate to a new focus in the literature concerning the co-construction and negotiation of desire as a powerful force in teaching and learning (Norton, 2016b). 
Those participants who love to teach also adore to marvel, answer questions, have an impact, transmit, be part of something, and experience. As Married revealed: "Today, we are both studying and working as English teachers, we love what we do and we are amazed at the things life has to offer." When exploring love, we agree with recent studies that relate it to learning (a discipline, knowledge, arts and crafts), to working, and to living (Mouton \& Montijo, 2017).

Imagination also constructs possible teacher identities and has lately received attention in relevant studies (Cheung, Said, \& Park, 2014). Participants who envision turning into English teachers also work, plan, find, achieve, try hard, persuade themselves, and graduate. Emma recapitulated: "I had to work extremely hard and retake several subjects. Even though I am still going through this complex process, I think this is the way to achieve my goal: becoming an English teacher."

Lastly, fluid identities struggle with graduate profiles mandated in the ETEP (Gorodetsky, \& Barak, 2016). These participants (be)come through tasks carried out inside and outside the university. These involve being (happy), (not) knowing, accomplishing, studying, continuing, believing, making decisions, travelling, and dreaming. Maggie explained that:

I am studying something that does not fulfil me a hundred per cent but it paves the way to accomplish my final goal. I am sure I will overcome it, as I want to keep on studying to become an interpreter.

We see that participants will not "turn into" teachers when receiving their diplomas. In the ETEP, their identities are co-formed by moral actions (Fenstermacher \& Richardson, 2005) and by third parties' designations. Thus, "to become a teacher we must not only graduate but also like what we do and feel that what we teach really touches our students" (Clara). Other identities acknowledge their oxymoronic nature (Martínez-Arbelaiz, Correa-Gorospe, \& Aberasturi-Apraiz, 2017), inhabiting "in-between two worlds" (Tute) as students and teachers.

Sometimes, lack of personal practical knowledge (Clandinin, 2015) is more restricting than the absence of a degree. Being a teacher "involves enjoying the freedom to deviate from the curriculum to teach other stuff rather than rushing to fulfill the objectives imposed by the 
academic coordinators" (Polka Dots). Briefly, these narratives retell processes involving co-compositions and re-negotiations of (future) teacher identities that exceed the confines of our ETEP classrooms.

These thematizations of desire, love, imagination, and fluidity contribute to narrative conceptualizations on EL teacher identity (Varghese, Motha, Trent, Park, \& Reeves, 2016). Our inquiry relates to studies acknowledging the need for different theoretical and methodological perspectives to explore the multifariousness of teacher identity construction processes (Costa \& Norton, 2017). Our contributions were achieved through the ontology and the epistemology of narrative inquiry that proffered narrative hospitality to our co-composed stories. This suggests that "the possibility of one's own story to be hosted in another's words and in a different narrative is grounded in the possibility of each person to tell her or his own story in different terms" (Pierosara, 2011, p. 74). Hosting narratives means welcoming them to co-construct, co-compose, and re-negotiate their meanings for EL teacher education.

This narrative inquiry bears ontological, epistemological, and ethical implications for teacher education programs because identity joins emotions and knowledge since student-teachers are committed to becoming (or not) "a certain kind of teacher." In this sense, these processes of co-constructing, co-composing, and re-negotiating teacher identities constitute assets for teacher education programs and should be included as very important elements in EL teacher curriculum designs (Correa-Gorospe, Martínez-Arbelaiz, \& Gutiérrez, 2014).

Finally, our inquiry has implications not only for teacher education but also for related professional development and research. Rising currents in these fields plead for a "critical conception" of different "identity theories" (Barahona, 2018, p. 7). These theories embrace reflection on social relationships that promote understanding of teacher education, development and research relevant to their own "glocal" contexts. 


\section{References}

Arnett, J. J. (2014). Emerging adulthood: The winding road from the late teens through the twenties. Oxford, UK: OUP.

Banegas, D. L. (2014). Initial English language teacher education: Processes and tensions towards a unifying curriculum in an Argentinian province. English Teaching: Practice and Critique, 13(1), 224-237.

Banegas, D. L. (2017). Initial English language teacher education: International perspectives on research, curriculum and practice. London-New York: Bloomsbury.

Banfi, C. (2013). The landscape of English teaching: Roots, routes and ramifications. In L. Renart \& D. L. Banegas (Eds.), Roots \& routes in language education: Bi-multi-plurilingualism, interculturality and identity. Selected papers from the $38^{\text {th }}$ FAAPI Conference (pp. 17-34). Buenos Aires, Argentina: FAAPI.

Barahona, M. (2018). Trends in teacher development programs. In J. I. Liontas (Ed.), The TESOL encyclopedia of English language teaching (pp. 1-14). Hoboken, NJ: John Wiley \& Sons.

British Council (2015). English in Argentina. An examination of policy, perceptions and influencing factors. Manchester, UK: British Council.

Canagarajah, S. (2016). TESOL as a professional community: A half-century of pedagogy, research, and theory. TESOL Quarterly, 50(1), 7-41.

Chen, J. (2016). Understanding teacher emotions: The development of a teacher emotion inventory. Teaching and Teacher Education, 55, 68-77.

Cheung, Y. L., Said, S. B., \& Park, K. (2014). Advances and current trends in language teacher identity research. London, UK: Routledge.

Clandinin, D. J. (2013). Engaging in narrative inquiry. London-New York: Routledge.

Clandinin, D. J. (2015). Stories to live by on the professional knowledge landscape. Waikato Journal of Education, 20(3), 183-193.

Clandinin, D. J., \& Huber, M. (2005). Shifting stories to live by. In D. Beijaard, P. C. Meijer, G. Morine-Dershimer, \& T. Harm (Eds.), Teacher professional development in changing conditions (pp. 43-59). Dordrecht, The Netherlands: Springer. 
Clandinin, D. J., \& Murphy, M. S. (2009). Comments on Coulter and Smith: Relational ontological commitments in narrative research. Educational Researcher, 38(8), 598-602.

Correa-Gorospe, J. M., Martínez-Arbelaiz, A., \& Gutiérrez, L. P. (2014). Between the real school and the ideal school: Another step in building a teaching identity. Educational Review, 66(4), 447-464.

Cortazzi, M. (2001). Narrative analysis in ethnography. In P. Atkinson, A. Coffey, S. Delamont, J. Lofland, \& L. Lofland (Eds.), Handbook of ethnography (pp. 384-395). London, UK: SAGE.

Costa, P. I., \& Norton, B. (2017). Introduction: Identity, transdisciplinarity, and the good language teacher. The Modern Language Journal, 101(S1), 3-14.

Craig, C. J. (2017). Sustaining teachers: Attending to the best-loved self in teacher education and beyond. In X. Zhu, A. L. Goodwin, \& H. Zhang (Eds.), Quality of teacher education and learning (pp. 193-205). Singapore: Springer.

Creese, A., \& Blackledge, A. (2015). Translanguaging and identity in educational settings. Annual Review of Applied Linguistics, 35, 20-35.

Douglas Fir Group (2016). A transdisciplinary framework for SLA in a multilingual world. The Modern Language Journal, 100(S1), 19-47.

Edwards, E., \& Burns, A. (2016). Language teacher-researcher identity negotiation: An ecological perspective. TESOL Quarterly, 50(3), 735-745.

Ellingson, L. L. (2009). Engaging crystallization in qualitative research: An introduction. Thousand Oaks, CA: SAGE.

Fenstermacher, G. \& Richardson, V. (2005). On making determinations of quality in teaching. Teachers' College Record, 107(1), 186-213.

Flores, M. A. (2017). The complexities and challenges of be(com)ing a teacher and a teacher educator. European Journal of Teacher Education, 40(1), 2-5.

Gale, T., \& Parker, S. (2014). Navigating change: A typology of student transition in higher education. Studies in Higher Education, 39(5), 734-753.

Giroir, S. (2014). "Even though I am married, I have a dream": Constructing L2 gendered identities through narratives of departure and arrival. Journal of Language, Identity \& Education, 13(5), 301-318.

Golombek, P., \& Doran, M. (2014). Unifying cognition, emotion, and activity in language teacher professional development. Teaching and Teacher Education, 39, 102-111. 
Gorodetsky, M., \& Barak, J. (2016). Becoming learners/teachers in nomadic space. Teachers and Teaching, 22(1), 84-100.

Huber, J., Caine, V., Huber, M., \& Steeves, P. (2013). Narrative inquiry as pedagogy in education. The extraordinary potential of living, telling, retelling, and reliving stories of experience. Review of Research in Education, 37(1), 212-242.

Instituto Nacional de Formación Docente \& Secretaría de Políticas Universitarias. (2011). Proyecto de mejora para la formación inicial de profesores para el nivel secundario. Áreas: Geografía, Historia, Lengua y Literatura y Lenguas Extranjeras. Buenos Aires, Argentina: Ministerio de Educación, Ciencia y Tecnología.

Johnson, K. E. (1992). Learning to teach: Instructional actions and decisions of preservice ESL teachers. TESOL Quarterly, 26(3), 507-535.

Kamhi-Stein, L. D., Díaz Maggioli, G., \& de Oliveira, L. C. (Eds.). (2017). English language teaching in South America: Policy, preparation and practices. Clevedon, UK: Multilingual Matters.

Kearns, S., \& Hart, N. (2017). Narratives of "doing, knowing, being and becoming": Examining the impact of an attachment-informed approach within initial teacher education. Teacher Development, 21(4), 511-527.

Kim, J. H. (2015). Understanding narrative inquiry: The crafting and analysis of stories as research. New York, NY: SAGE.

McAdams, D. P. (2018). Narrative identity: What is it? What does it do? How do you measure it? Imagination, Cognition and Personality, 37(3), 359-372.

Martínez-Arbelaiz, A., Correa-Gorospe, J. M., \& Aberasturi-Apraiz, E. (2017). Communities of practice and negotiation of meaning among pre-service teachers. In J. McDonald \& A. Cater-Steel (Eds.), Communities of practice (pp. 525-543). Singapore: Springer.

Meijer, P. C. (2017). Essential issues in developing a professional identity as a teacher. In X. Zhu, A. L. Goodwin, \& H. Zhang (Eds.), Quality of teacher education and learning (pp. 207-223). Singapore: Springer.

Mercer, S., Oberdorfer, P., \& Saleem, M. (2016). Helping language teachers to thrive: Using positive psychology to promote teachers' professional well-being. In D. Gabryś-Barker \& D. Gałajda (Eds.), Positive psychology perspectives on foreign language learning and teaching (pp. 213-229). Basel, Switzerland: Springer. 
Mouton, A. R., \& Montijo, M. N. (2017). Love, passion, and peak experience: A qualitative study on six continents. The Journal of Positive Psychology, 12(3), 263-280.

Norton, B. (1997). Language, identity, and the ownership of English. TESOL Quarterly, 31(3), 409-429.

Norton, B. (2016a). Identity and language learning: Back to the future. TESOL Quarterly, 50(2), 475-479.

Norton, B. (2016b). Learner investment and language teacher identity. In G. Barkhuizen (Ed.), Reflections on language teacher identity research (pp. 80-86). New York, NY: Routledge.

Orland-Barak, L. (2016). Doing, becoming and being a teacher: Connections, controversies and disconnections. Teachers and Teaching, 22(1), 1-5.

Pierosara, S. (2011). Asking for narratives to be recognized: The moral of histories. Études Ricoeuriennes/Ricoeur Studies, 2(1), 70-83.

Pinnegar, S., \& Daynes, J. G. (2007). Locating narrative inquiry historically. In D. J. Clandinin (Ed.), Handbook of narrative inquiry: Mapping a methodology (pp. 3-34). Thousand Oaks, CA: SAGE.

Pinnegar, S. E., \& Hamilton, M. L. (2015). Knowing, becoming, doing as teacher educators: Identity, intimate scholarship, inquiry. Bingley: Emerald Group.

Porto, M. (2016). English language education in primary schooling in Argentina. Education Policy Analysis Archives, 24(80), 1-29.

Porto, M., Montemayor-Borsinger, A., \& López-Barrios, M. (2016). Research on English language teaching and learning in Argentina (2007-2013). Language Teaching, 49(3), 356-389.

Ramezanzadeh, A., Adel, S. M. R., \& Zareian, G. (2016). Authenticity in teaching and teachers' emotions: A hermeneutic phenomenological study of the classroom reality. Teaching in Higher Education, 21(7), 807-824.

Ricoeur, P. (1990). Soi-Même comme un autre. Paris, France: Editions du Seuil.

Salinas, D., \& Ayala, M. (2018). EFL student-teachers' identity construction: A case study in Chile. HOW Journal, 25(1), 33-49.

Schutz, P. A., Hong, J. Y., Cross, D. I., \& Osbon, J. N. (2006). Reflections on investigating emotion in educational activity settings. Educational Psychology Review, 18(4), 343-360.

Sfard, A., \& Prusak, A. (2005). Telling identities: In search of an analytic tool for investigating learning as a culturally shaped activity. Educational Researcher, 34(4), 14-22. 
Shapiro, S. (2010). Revisiting the teachers' lounge: Reflections on emotional experience and teacher identity. Teaching and Teacher Education, 26(3), 616-621.

Spector-Mersel, G. (2011). Mechanisms of selection in claiming narrative identities: A model for interpreting narratives. Qualitative Inquiry, 17(2), 172-185.

Van Manen, M. (1990). Researching lived experience. New York, NY: SUNY Press.

Varghese, M. M., Morgan, B., Johnston, B., \& Johnson, K. A. (2005). Theorizing language teacher identity: Three perspectives and beyond. Journal of Language, Identity \& Education, 4(1), 21-44.

Varghese, M. M., Motha, S., Trent, J., Park, G., \& Reeves, J. (2016). Language teacher identity in multilingual settings. TESOL Quarterly, 50(3), 545-571.

Tracy, S. J. (2010). Qualitative quality: Eight "big-tent" criteria for excellent qualitative research. Qualitative Inquiry, 16(10), 837-851.

Zembylas, M. (2007). Risks and pleasures: A Deleuzo-Guattarian pedagogy of desire in education. British Educational Research Journal, 33(3), 331-347. 
